\title{
Recent Publications on Japan from the Institute of Oriental and Occidental Studies and Kansai University Press
}

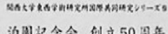
記 念論文 集

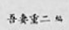

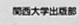

Hakuen kinenkai sōritsu 50 shūnen kinenronbunshū 泊 園記念創立50周年記念論文集 (Collection of Commemorative Essays on the Fiftieth Anniversary of the Establishment of the Memorial Association for Hakuen Academy), Azuma Jūji 吾妻重二, ed. (A5 size), $¥ 4000$.

A collection of commemorative essays from the 2010 international symposium, "Traditional Education in East Asia and Hakuen Academy."

Hakuen Shoin shiryō shūsei, Volumes 1-2 泊園書院資料 集成 (Compilation of Materials on Hakuen Academy, Volumes 1-2), Azuma Jūji 吾妻重二, ed. (A5/B5 size), $¥ 5000 / ¥ 6000$.

Volume 1 is Hakuen Shoin shiryōshū 泊園書院資料集 (Collection of Materials on Hakuen Academy); Volume 2 is Hakuen bunko inpushū 泊園文庫印譜集 (Collection of the Book of Seals from the Hakuen library.

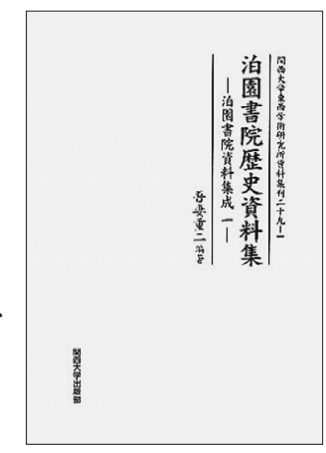

* Kansai University Press

3-3-35 Yamate-chō, Suita City, Osaka-fu, 564-8680

Tel: 06-6368-0238 Fax: 06-6389-5162

The Compilation of Japan-related publications was done by Professors TAO De-min and INOUE Katsuhito when they were hosting the 2016 annual meeting of the Nihon shisōshi Gakkai (Association of Japanese Intellectual History). 
Karei bunken shūsei, Nihonhen 家礼文献集成 日本篇, 16 (Compilation of Materials on Zhuxi Family Rituals, Volumes 1-6 on Japan), Azuma Jūji 吾妻重二, ed. (B5 size), $¥ 4,000-¥ 5,200$.

A collection of works by Hayashi Gahō (林黛峰), the Mito School, Nakamura Tekisai (中村惕斎), Masuda Rikken (増田立軒), Ōwada Kikyū (大和田気求), Muro Kyūsō (室鳩巣), Asami Keisai (浅見絧斎), and others.
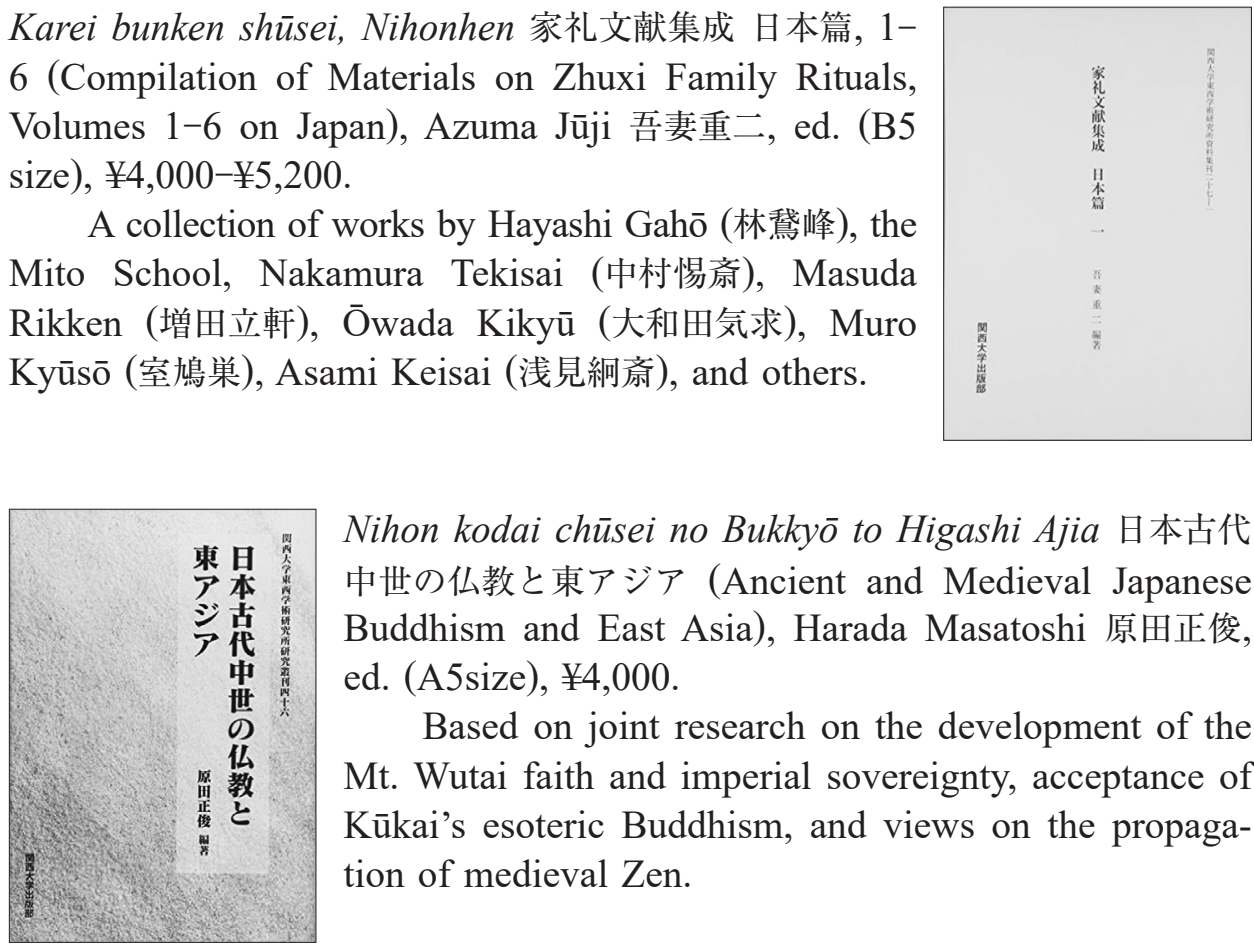

Nihon kodai chūsei no Bukkyō to Higashi Ajia 日本古代 中世の仏教と東アジア (Ancient and Medieval Japanese Buddhism and East Asia), Harada Masatoshi 原田正俊, ed. (A5size), ¥4,000.

Based on joint research on the development of the Mt. Wutai faith and imperial sovereignty, acceptance of Kūkai's esoteric Buddhism, and views on the propagation of medieval Zen.

Nagasaki Tōkanzu shūsei: Kinsei Nicchū kōshōshiryōshū 6 長崎唐館図集成一近世日中交涉史料集 6 (Compilation of Pictures of the Chinese Settlement in Nagasaki: Collection of Documents on Early-Modern Sino-Japanese Interaction History), Ōba Osamu 大庭脩, ed. (A4 size), $¥ 13,500$.

Comprehensive collection of works found in the Nagasaki Municipal Museum, the Kobe City Museum, and Peabody Essex Museum.
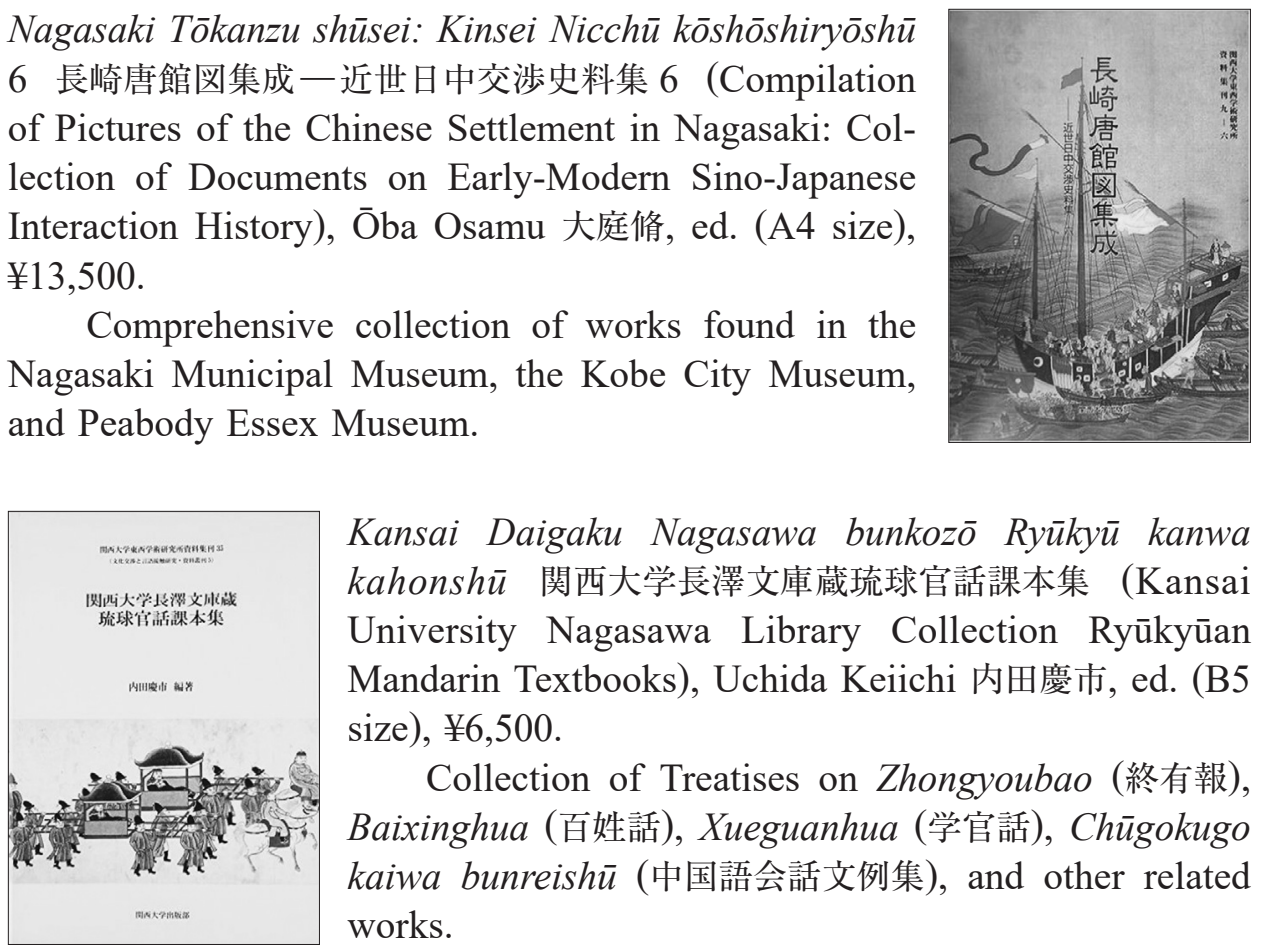

Kansai Daigaku Nagasawa bunkozō Ryūkyū kanwa kahonsh $\bar{u}$ 関西大学長澤文庫蔵琉球官話課本集（Kansai University Nagasawa Library Collection Ryūkyūan Mandarin Textbooks), Uchida Keiichi 内田慶市, ed. (B5 size), $¥ 6,500$.

Collection of Treatises on Zhongyoubao (終有報), Baixinghua (百姓話), Xueguanhua (学官話), Chūgokugo kaiwa bunreishū (中国語会話文例集), and other related works. 
Edo jidai no Tōwa ni kansuru kiso kenkyū 江戸時代の唐 話に関する基礎研究 (Fundamental Research on Chinese Language Study in the Edo Period), Okumura Kayoko, 奥村佳代子 (A5 size), $¥ 5,000$.

A bird's-eye view of the phenomenon of Tōwa based on Tōwa materials recorded in Okajima Kanzan's (岡島 冠山) Tōwa sanyo 唐話纂要 and interpreting of Chinese that occurred in Nagasaki, the Satsuma domain, and the Ryūkyū Kingdom.
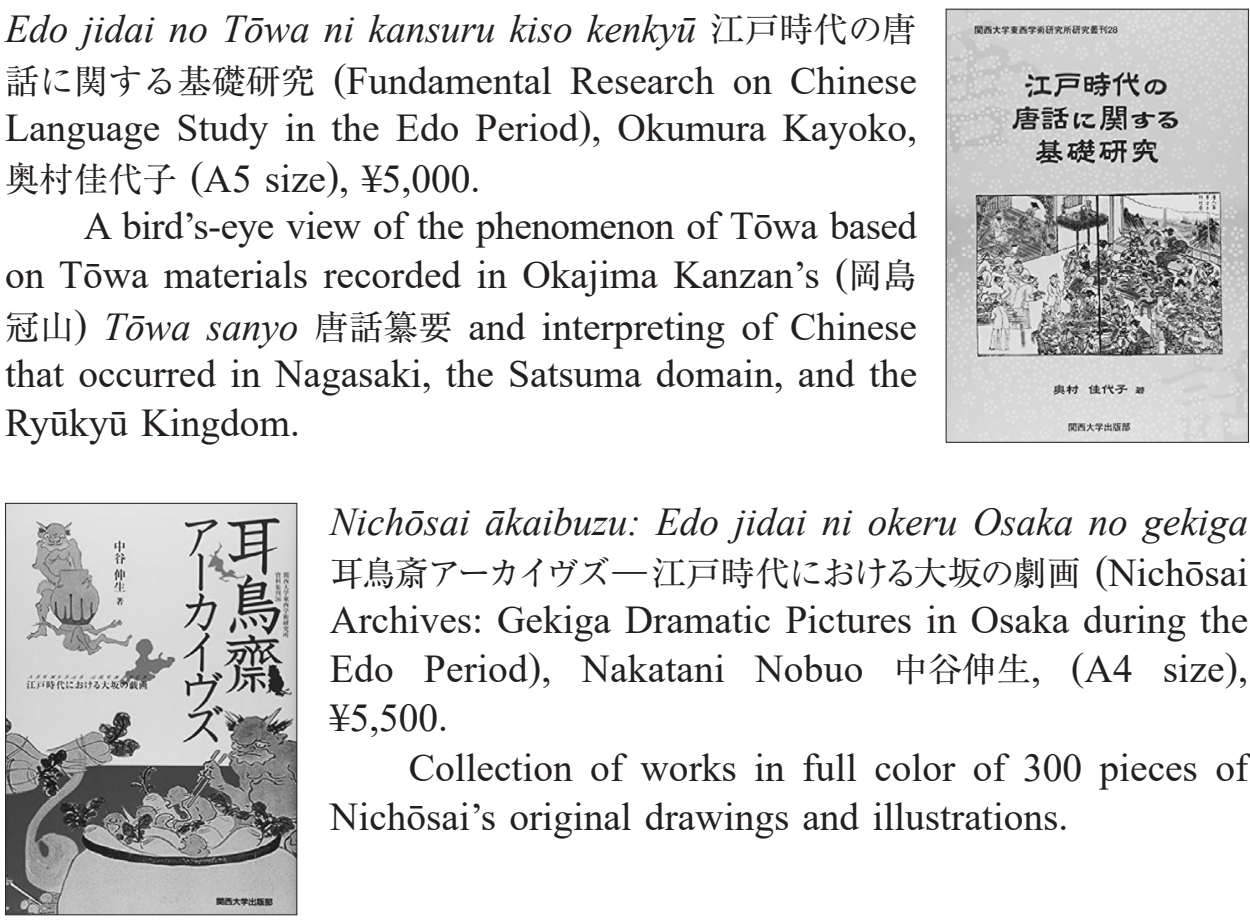

Nichōsai ākaibuzu: Edo jidai ni okeru Osaka no gekiga 耳鳥斎アーカイヴズ一江戸時代に打ける大坂の劇画 (Nichōsai Archives: Gekiga Dramatic Pictures in Osaka during the Edo Period), Nakatani Nobuo 中谷伸生, (A4 size), $¥ 5,500$.

Collection of works in full color of 300 pieces of Nichōsai's original drawings and illustrations.

Higashi Ajia no bunjin sekai to Noro Kaiseki: Chügoku, Taiwan, Kankoku, Nihon, Pōrando kara no kōsatsu 東了 ジアの文人世界と野呂介石一中国・台湾・韓国・日本・ポー ランドからの考察 (Noro Kaiseki and the Literati World in East Asia: Studies from China, Taiwan, Korea, Japan, and Poland), Nakatani Nobuo 中谷伸生, ed. (B5 size), $¥ 3,700$. List of all of the works in "Nanki sansui shaseicho" 南紀山水写生帳 by Noro, who has heretofore not been researched. The text introduces various aspects of the literati painter Noro from the standpoint of art history.
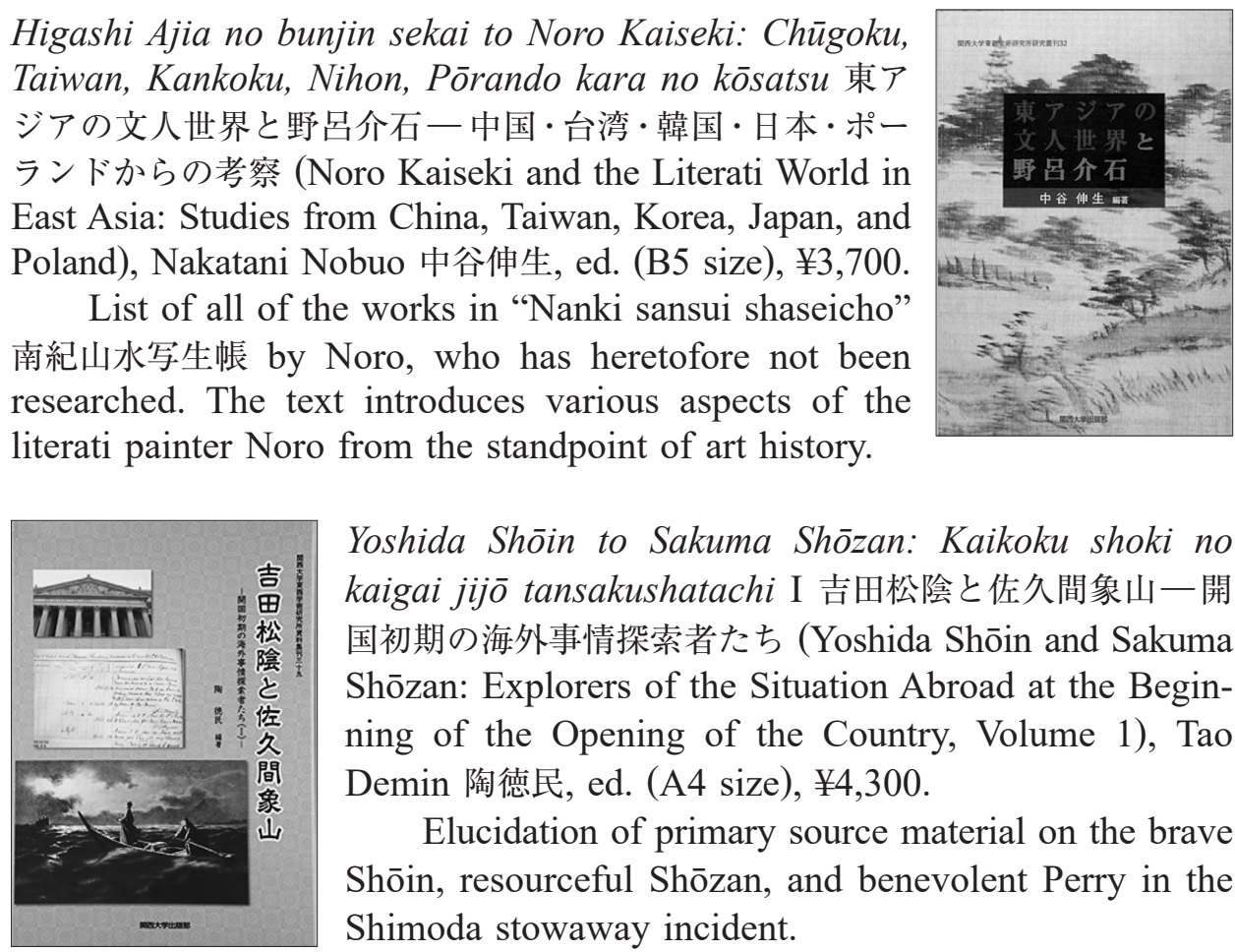

Yoshida Shōin to Sakuma Shōzan: Kaikoku shoki no kaigai jijo tansakushatachi I 吉田松陰と佐久間象山一開 国初期の海外事情探索者たち (Yoshida Shōin and Sakuma Shōzan: Explorers of the Situation Abroad at the Beginning of the Opening of the Country, Volume 1), Tao Demin 陶德民, ed. (A4 size), $¥ 4,300$.

Elucidation of primary source material on the brave Shōin, resourceful Shōzan, and benevolent Perry in the Shimoda stowaway incident. 
Shigeno Yasutsugu ni okeru gaikō, kanbun to kokushi: Osaka Daigaku Kaitokudō Bunko Nishimura Tensh̄̄ kyūzō shahon sanshu 重野安繹に打ける外交、漢文と国史 一大阪大学懐徳堂文庫西村天囚旧藏写本三種（The Diplomacy, Kanbun, and National History of Shigeno Yasutsugu: Three Types of Manuscripts in the Osaka University Kaitokudō Library Previously Held by Nishimura Tenshū), Tao Demin 陶徳民, ed., (A4 size), ¥6,000.

Contains the works, Record of the Yokohama Reception Room (横濱應接記), Lectures on Kanbun (漢文講義), and Summary Outline of the History of Greater Japan (大 日本歴史略説).

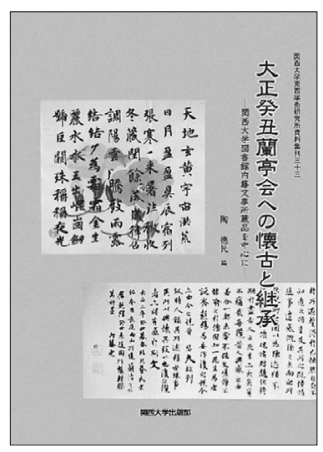

Taishō mizunotoshi Ranteikai e no kaiko to keishō: Kansai Daigaku toshokan Naitō Bunko shozōhin o chūshin $n i$ 大正癸丑蘭亭会への懐古と継承一関西大学図書 館内藤文庫所藏品を中心に一 (Reminisces and Inheritance of the Lanting Meeting in 1913: Centering on the Collection in the Naitō Konan Library held in Kansai University Library), Tao Demin 陶徳民, ed. (A4 size), $¥ 6,600$.

Includes pictures and documents related to the Lanting Commemoration Meeting held in 1913 in Kyoto, Tokyo, Beijing, and Hangzhou.

Naitō Konan to Shinjin shoga: Kansai Daigaku toshokan Naitō Bunko shozōhinshū 内藤湖南と清人書画一関西大学 図書館内藤文庫所蔵品集 (Naitō Konan and the Paintings and Calligraphic Works of Qing Dynasty Individuals: The Naitō Library Collection Held in Kansai University Library), Tao Demin 陶徳民, ed. (A4 size), ¥5,500.

A collection of seventeen valuable pieces of art and calligraphic works by Dai Zhen (戴震), Zhang Xuecheng (章学誠), Ye Dehui (葉德輝), Luo Zhenyu (羅振玉), Zheng

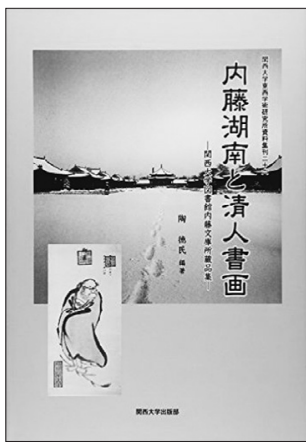
Xiaoyu (鄭孝胥), Puyi (溥儀), and others. 


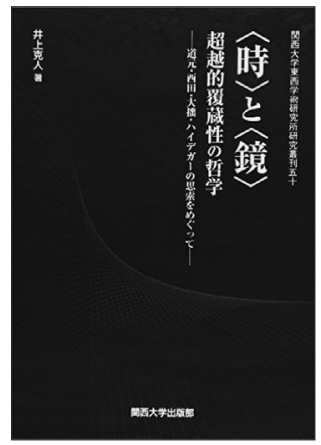

"Toki" to "kagami" chōetsuteki fukuzōsei no tetsugaku: Dōgen, Nishida, Daisetsu, Haidegā no shisaku o megutte 「時」と「鏡」超越的覆蔵性の哲学一道元、西田、大拙、ハイ デガーの思索をめぐってー (Philosophy of the Transcendental Hidden Inner Feelings of "Time" and "Mirror": Focusing on the Contemplations of Dōgen, Nishida, Suzuki Daisetsu, and Heidegger), Inoue Katsuhito 井上 克人, (A5 size), ¥4,500.

Reading from a religio-philosophical viewpoint the underlying dimension of transcendentalism in the contemplations of the four authors.

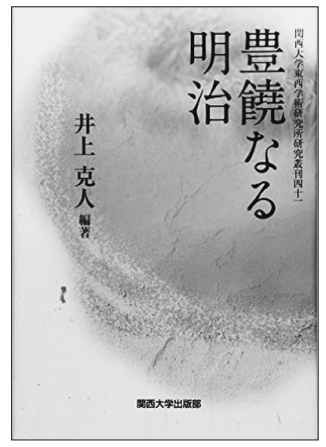

Hōjōnaru Meiji 豊饒なる明治 (The Productive Meiji), Inoue Katsuhito 井上克人, ed. (A5 size), ¥3,400.

Elucidates the "dauntless ethical consciousness" and "nativist community consciousness" underlying education in classical Chinese texts.

Sensō no kiroku to hyōshō: Nihon, Ajia, Yōroppa(Records and Representation of War: Japan, Asia, Europe), Masuda Chikako 増田周子, ed. (B5 size), $¥ 3,200$.

Collection of essays from a joint Korean-Japanese international symposium held in 2013. Discussion of the search for a road to peace.
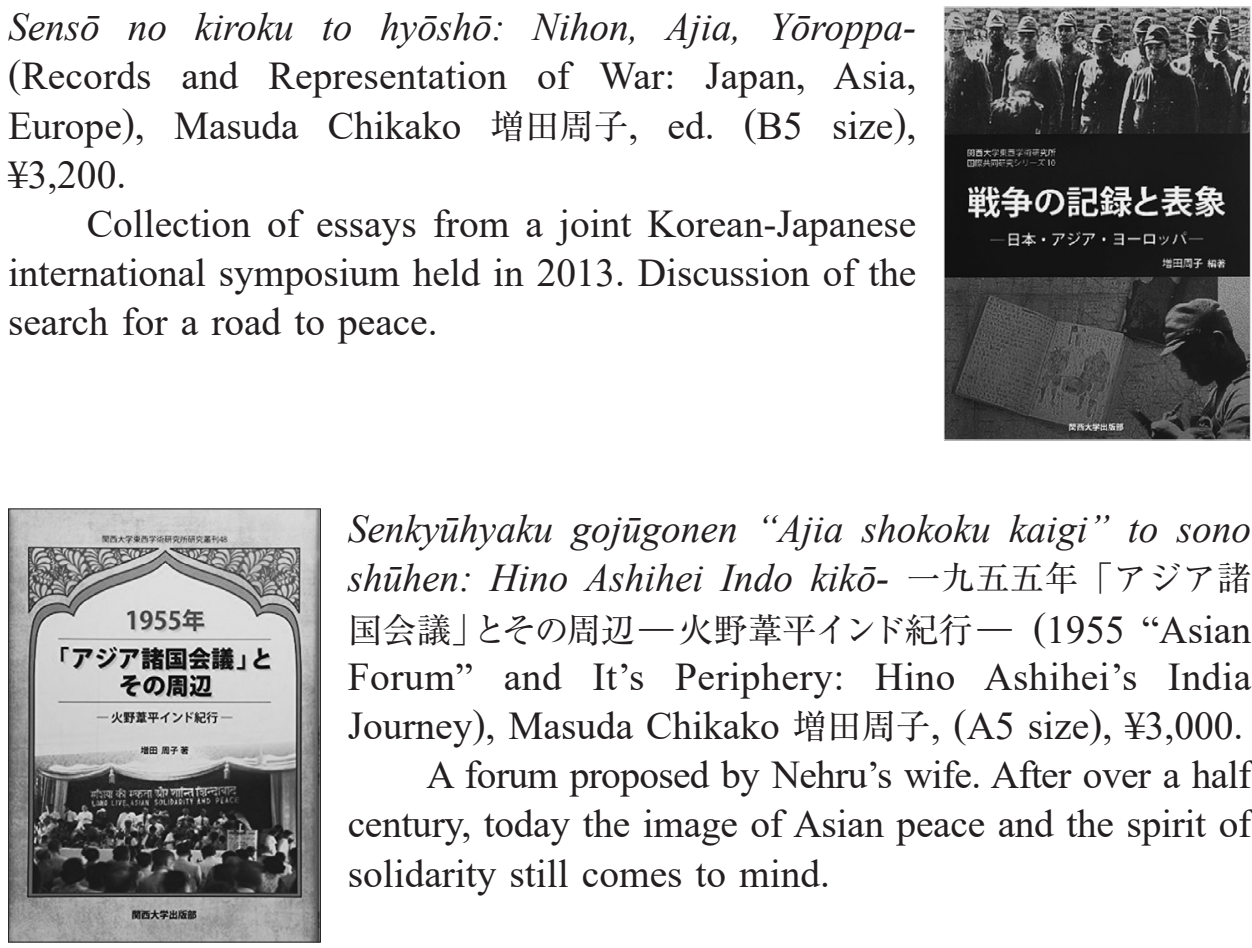

Senkyūhyaku gojūgonen "Ajia shokoku kaigi" to sono shūhen: Hino Ashihei Indo kikō- 一九五五年「アジア諸 国会議」とその周辺一火野莘平インド紀行一 (1955 “Asian Forum" and It's Periphery: Hino Ashihei's India Journey), Masuda Chikako 増田周子, (A5 size), ¥3,000.

A forum proposed by Nehru's wife. After over a half century, today the image of Asian peace and the spirit of solidarity still comes to mind. 